http://dx.doi.org/10.5902/2236117027692

Revista do Centro do Ciências Naturais e Exatas - UFSM, Santa Maria

Revista Eletrônica em Gestão, Educação e Tecnologia Ambiental - REGET

e-ISSN 22361170 - V. 21, n. 3, set - dez. 2017, p.259-264

\title{
Experimental study of the effect of temperature on the drying process and volume shrinkage of oats
}

\author{
${ }^{1}$ Camila Nicola Boeri Di Domenico, Laís Fabiana Serafini, Maurício Bavaresco \\ ${ }^{1}$ UTFPR - Francisco Beltrão
}

camiladomenico@utfpr.edu.br; lais.serafini@hotmail.com; mauricio-bava@hotmail.com

\begin{abstract}
This study aimed to determine the effect of air temperature on the drying kinetics and volume shrinkage of oat grains. Grains with an initial moisture content of $17 \%(\mathrm{db})$ were selected and dried in a forced air circulation oven under three temperature conditions: 65,75 and $85^{\circ} \mathrm{C}$. To ascertain the volume shrinkage, the grains were dried in trays and then placed in a graduated cylinder. Volume reduction of the grains was monitored throughout the drying process. As the temperature of the drying air increased, the time of the reduction process decreased. The rate of volume shrinkage decreased during drying and this effect was intensified with increasing temperature.
\end{abstract}

Keywords: Drying; oats; volume shrinkage 


\section{INTRODUCTION}

In Brazil, although there are perennial varieties, oats have been cultivated as annual crops since 1600 (Matzenbacher, 1999). Oats are used an alternative for winter grain production in the states of Paraná, Santa Catarina and Rio Grande do Sul (Fontanell et al., 1996).

The production of healthy, high quality grains requires that the crop be harvested early when there is still a high moisture content in the grains. This minimizes the losses caused by insects and microorganisms in the field.

The drying of agricultural products is the most widely used process to ensure their quality and stability after harvesting. Drying reduces the amount of water in the grains and, consequently, affects the biological activity and the chemical and physical changes that occur during storage. However, the reduction of moisture content in the grains involves processes of heat and mass transfer simultaneously, and, depending on the method and the drying conditions, the quality and physical properties of the grains may be altered substantially (Hall, 1980).

The physical properties of the grains are key factors in the optimization of industrial processes and in the development of new projects and equipment that is used in post-harvest operations. Variations in these physical properties, due to moisture content and drying processes, have been studied by various authors on several other products (Mcminn \& Magee, 1997; Ruffato et al., 1999).

According to Araújo et al. (2014), each product behaves differently during the drying process because of their unique physical and chemical attributes. Therefore, information about these unique features is relevant to assist in post-harvest processing. Furthermore, the data is given to engineers and designers to aid the development of machinery, structures and processes that will improve equipment and operational efficiency.

One of the most important physical changes that occurs in agricultural products during drying is the reduction of volume. The loss of water causes damage to the cell structure, resulting in a change in shape and a decrease in size (Mayor \& Sereno, 2004). The nature of this change is dependent on the drying process and the type of product. According to Ramos et al. (2003), this phenomenon of the reduction of moisture content during the drying process, which causes a reduction in the size of cell tissue, is usually called volume shrinkage.

Siqueira, Resende and Chaves (2012) believe that studying volume shrinkage during the drying process is essential for the development of new drying equipment, as observing the reduction of moisture content of the grain makes it possible to predict the corresponding mass reduction.

Besides causing volume shrinkage, the reduction of moisture content of the grains directly alters their physical properties during drying. Thus, the accurate description of the physical properties is of utmost importance to optimize industrial processes, and the design and scale of harvest equipment and post-harvest operations (Resende et al., 2007).

Given the scientific and technological importance of drying processes, the present study aims to analyze the effects of drying on the volume shrinkage of oats under different temperature conditions.

\section{MATERIALS AND METHODS}

\section{ExPerimental Procedure}

This study was carried out at the Chemistry Laboratory of the Federal University of Technology - Paraná, Francisco Beltrão Campus. For the experiments, white oat grains originating from the city of Sarandi, in the state of Rio Grande do Sul, were used.

First, the grains were selected and the samples were prepared. The samples were separated for the drying process and the initial moisture content of the grains was determined.

The initial dry basis moisture content of each sample was calculated according to equation 1 . Following the standards set by the Ministry of Agriculture, $15 \mathrm{~g} / 20 \mathrm{~g}$ of the product was placed in an oven at a temperature of $105^{\circ} \mathrm{C}$, for 24 hours.

$$
X_{b s}=\frac{m_{0}-m_{f}}{m_{f}} .100
$$


where:

$$
\begin{aligned}
& X_{b s}=\text { moisture content, dry basis }(\%) ; \\
& m_{0}=\text { initial mass }(\mathrm{g}) ; \\
& m_{f}=\text { final mass }(\mathrm{g}) .
\end{aligned}
$$

Thus, the difference between the initial mass and the final mass of the grains after this process occurs, is the mass of water contained in the product. This method considers that only water evaporation takes place, and does not take the mass of other evaporating gases into account.

In the experiments, oat samples were dried in a forced air circulation oven at controlled air temperatures of $65^{\circ} \mathrm{C}, 75^{\circ} \mathrm{C}$ and $85^{\circ} \mathrm{C}$, and the mass of each sample was taken periodically. Each measurement was taken twice.

Taking the mass of the sample at each time interval, it was possible to determine the moisture content at a certain instant through the expression described by equation 2 :

$$
X=\frac{\left(X_{f}-X_{0}\right) \cdot\left(m-m_{0}\right)}{\left(m_{f}-m_{0}\right)}+X_{0}
$$

where:

$X=$ moisture content at a certain instant, dry basis (\%);

$X_{0}=$ initial moisture content, dry basis (\%);

$m=$ mass at a certain instant $(\mathrm{g})$;

In a similar process to that of calculating the initial moisture content, the final moisture content was determined from the sample removed from the dryer at the end of each experiment.

Using the values of sample's moisture contents (initial, final and at certain instants), the values of the non-dimensional moisture content were obtained for each drying process. These measurements enabled the comparison of the different drying curves and the analysis of the influence of temperature on the drying kinetics, according to equation 3:

$$
X_{a d}=\frac{X-X_{f}}{X_{0}-X_{f}}
$$

To obtain the volume shrinkage of the mass, the oat samples were placed under each experimental condition previously described, and their volume reduction during drying was measured using a graduate cylinder. Each measurement was repeated three times.

The volume shrinkage ratio was determined by the relationship between the volumetric moisture content and the initial volume, according to equation 4 :

$$
\Psi=\frac{V}{V_{i}}
$$

where:

$\Psi=$ volume shrinkage ratio, decimal;

$\mathrm{V}=$ volumetric moisture content, $\mathrm{m}^{3}$;

$\mathrm{V}_{\mathrm{i}}=$ initial volume, $\mathrm{m}^{3}$. 


\section{DATA ANALYSIS}

The drying kinetics and volume shrinkage of the oat grains were analyzed during drying for all the temperature test conditions, and the influence of this parameter on the process was evaluated.

\section{RESULTS AND DISCUSSION}

The initial water content of the oat grains was approximately $17 \%(\mathrm{db})$.

The comparison between the drying curves for the 65,75 and $85^{\circ} \mathrm{C}$ temperatures for the oat grains are shown in figure 1:

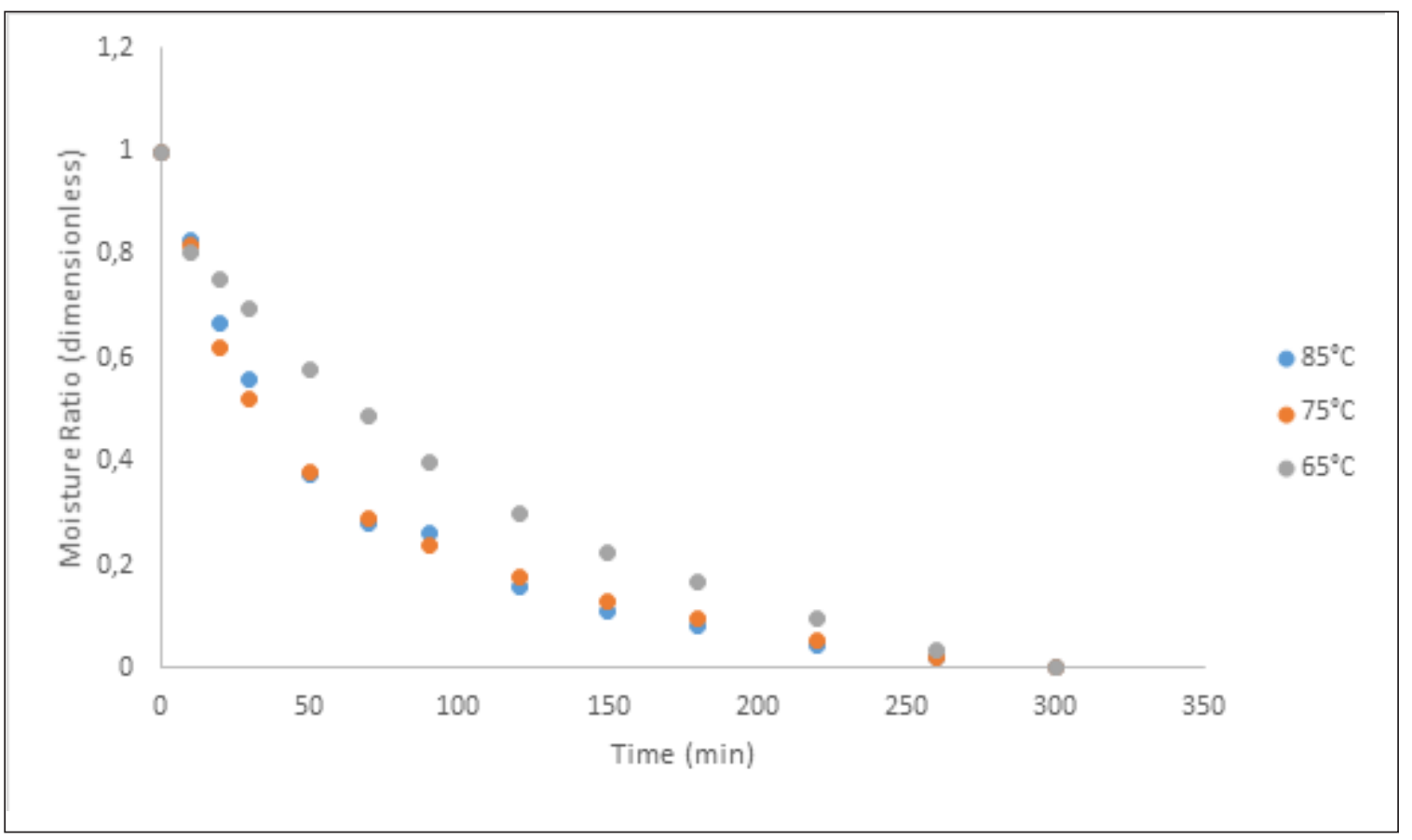

Figure 1 - Influence of temperature on drying kinetics of oats (Source: Author, 2017)

It was observed that with the increase of air temperature there was a decrease in the drying time, clearly showing the increased rate of water withdrawal and proving that temperature directly influences the drying process. This occurs due to the increase in the energy available for water evaporation and the increase of the mass transfer coefficient corresponding to the increase of the drying air temperature.

In figure 2 , the comparative data of the volume shrinkage ratio of the oat grains in relation to the drying time is presented for the temperatures of 65,75 and $85^{\circ} \mathrm{C}$.

It is verified that at the temperature of $85^{\circ} \mathrm{C}$, that is, at the highest temperature, the oats contracted in a shorter amount of time, showing that the increase in temperature promoted greater volume shrinkage of the oats. This decrease in volume occurs because of the reduction in cell tissue size resulting from the reduction of the moisture content during the drying process. Volume shrinkage of the grain mass creates empty spaces inside the dryer which increases the passage of hot air and can increase the risk of fire in the dryers.

Such behavior was also identified by Smaniotto (2016) in a study with sunflower grains; Oliveira et al. (2013) in the drying of soybean grains at two different temperatures; Goneli et al. (2007) working with wheat grains at different temperatures; as well as by Afonso Júnior and Corrêa (2000), studying the contraction kinetics of the popcorn varieties CMS 43 and Zélia at different temperatures. 


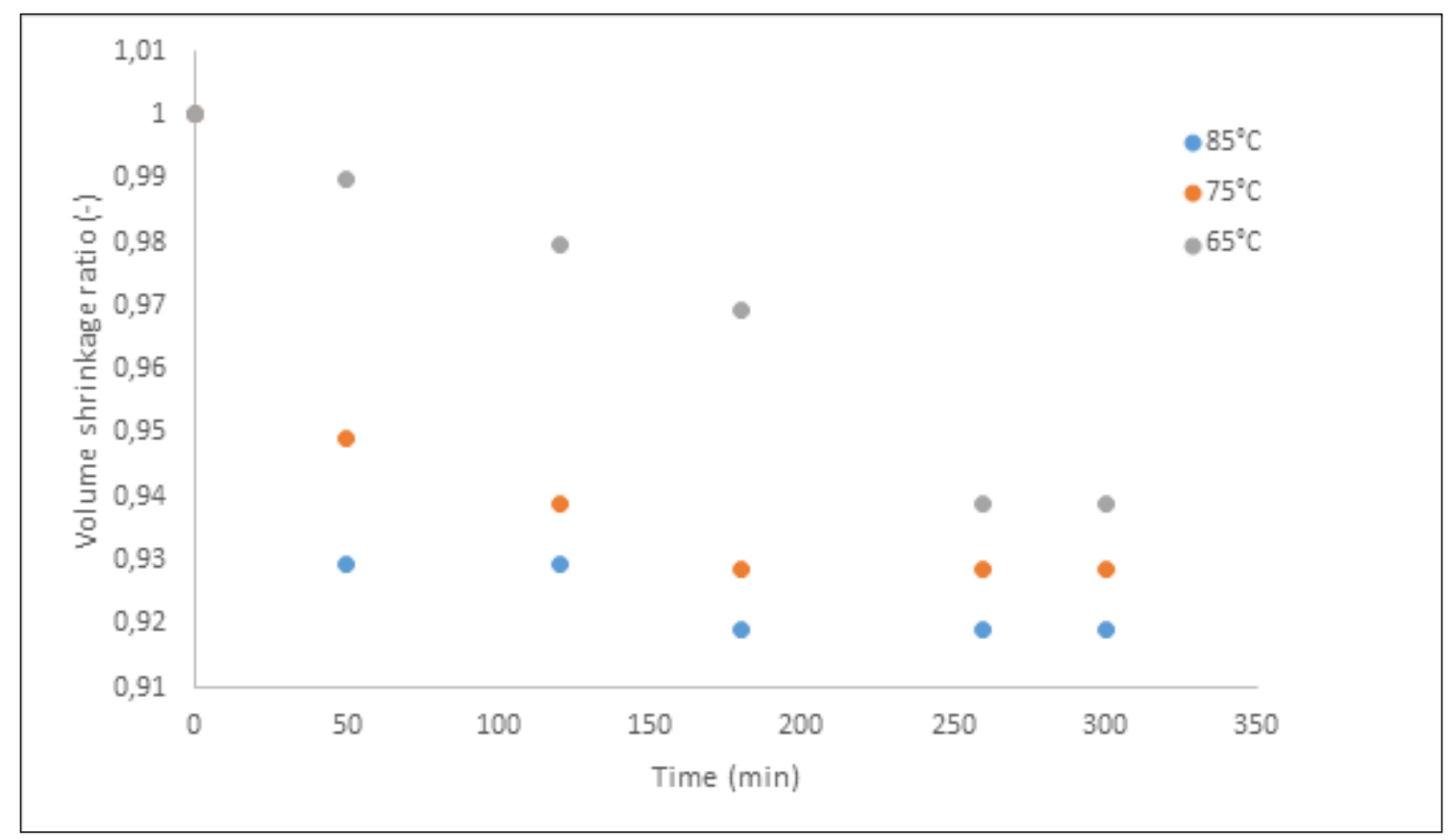

Figure 2 - Volume shrinkage ratio in relation to the drying time for different temperatures (Source: Author, 2017)

\section{FINAL CONSIDERATIONS}

The increase in temperature from $65^{\circ} \mathrm{C}$ to $85^{\circ} \mathrm{C}$ decreased the drying time, showing that temperature directly affects the drying kinetics of oats.

The volume shrinkage ratio of the oat grains decreases during drying, and this effect is intensified with increasing temperature. The increase in the drying rate, due to the elevation of the air temperature, is closely related to the process of reduction and greatly accelerates the shrinkage of the oats.

\section{REFERENCES}

Afonso Júnior, P.C.; Corrêa, P.C.; Pinto, F.A.C.; Sampaio, C.P. Shrinkage evaluation of five different varieties of coffee berries during the drying process. Biosystems Engineering, v.86, p.481-485, 2003.

Araújo, W.D.; Goneli, A.L.D.; Souza, C.M.A.; Gonçalves, A.A.; Vilhasantis, H.C.B. Propriedades físicas dos grãos de amendoim durante a secagem. Revista Brasileira de Engenharia Agrícola e Ambiental, v.18, p.279286, 2014.

Fontaneli, R.S.; Fontaneli, R.S.; Silva, G. da; et al. Avaliação de cereais de inverno para duplo propósito. Pesquisa Agropecuária Brasileira, Brasília, v. 31, n. 1, 1996.

Goneli, A.L.D.; Corrêa, P.C.; Magalhães, F.E.A.; Baptestin, F.M. Contração volumétrica e forma dos frutos de mamona durante a secagem. Acta Scientiarum. Agronomy, v.33, p.1-8, 2011.

Goneli, A.L.D.; Corrêa, P.C; Resende, O.; Reis Neto, S.A. Estudo da difusão de umidade em grãos de trigo durante a secagem. Ciência Tecnologia Alimento, Campinas, v.27, p. 135-140, 2007.

Hall, C. W. Drying and storage of agricultural crops. Westport: AVI, 1980. 381p.

Mcminn, W. A. M.; Magee, T. R. A. Physical characteristics of dehydrated potatoes - part I. Journal of Food Engineering, London, v.33, n.1-2, p.37-48, 1997. 
Matzenbacher, R.G. A cultura da aveia no sistema plantio direto. Cruz Alta: FUNDACEP - FECOTRIGO, 1999. $200 \mathrm{p}$.

Oliveira, D.E.C.; Resende. O.; Smaniotto, T.A.S.; Siqueira, V.C.; Neto, C.A.J. Alterações morfométricas em grãos de soja durante o processo de secagem. Semina: Ciências Agrárias, Londrina, v. 34, p. 975-984. 2013.

Resende, O.; Corrêa, P. C.; Goneli, A. L. D.; Cecon, P. R. Forma, tamanho e contração volumétrica do feijão (Phaseolus vulgaris L.) durante a secagem. Revista Brasileira de Produtos Agroindustriais, v.7, p.15-24, 2005.

Ruffato, S.; Corrêa, P. C.; Martins, J. H.; Mantovani, B. H. M.; Silva, J. N. Influência do processo de secagem sobre a massa específica aparente, massa específica unitária e porosidade de milho-pipoca. Revista Brasileira de Engenharia Agrícola e Ambiental, Campina Grande, v.3, n.1, p.45-48, 1999.

Siqueira, V. C.; Resende, O; Chaves, T. H. Propriedades físicas das sementes de pinhão-manso ao longo da secagem em diferentes temperaturas. Semina: Ciências Agrárias, Londrina, v. 33, p. 2705-2714, 2012.

Smaniotto, T. A. S. Secagem e armazenamento de grãos de girassol. Tese de Doutorado, Programa de Pós-Graduação em Ciências Agrárias do Instituto Federal de Educação, Ciência e Tecnologia Goiano - Campus Rio Verde, 2016. 